\title{
Telaah Regulasi Ojek Online di Indonesia dalam Perspektif Filsafat Fenomenologi Hukum
}

\author{
Ayuta Puspa Citra Zuama ${ }^{1}$, Cut Mutia Dinda ${ }^{2}$, dan Djalu Pamungkas ${ }^{3}$ \\ ${ }^{1,2,3}$ Fakultas Hukum, Universitas Sebelas Maret \\ Corresponding author. Email : ayutapuspa@gmail.com
}

Naskah diterima: 16-12-2020 revisi: 29-01-2021; disetujui: 18-05-2021

DOI: https://doi.org/10.46257/jrh.v25i1.182

\begin{abstract}
Abstrak
Moda transportasi umum mengalami perkembangan teknologi yang cukup memudahkan akses bagi para calon penumpangnya, seperti yang semula konvensional menjadi transportasi online. Namun, operasional perusahaan penyedia jasa transportasi online dinyatakan menjalankan bisnis ilegal karena sejak awal tidak memenuhi ketentuan pasal 1 angka 21 UndangUndang Nomor 22 Tahun 2009 tentang Lalu Lintas dan Angkutan Jalan (UU LLAJ) dan tidak mengantongi izin usaha sebagai penyedia jasa transportasi umum. Lalu pada Tahun 2019 Menteri Perhubungan Republik Indonesia mengeluarkan Peraturan Menteri Nomor 12 Tahun 2019 tentang Perlindungan Keselamatan Pengguna Sepeda Motor yang Digunakan untuk Kepentingan Masyarakat. Peraturan Menteri ini keluar menghiraukan kesemrawutan peraturan perundang-undangan lainnya sebagai terobosan baru yang diharapkan dapat menjadi solusi atas permasalahan pengaturan ojek online. Berdasarkan problematika hukum terkait dengan regulasi ojek online penulis tertarik untuk melakukan penelitian mengenai kebutuhan hukum untuk melakukan regulasi terhadap ojek online di Indonesia berdasarkan perspektif filsafat fenomenologi hukum. Penelitian ini menggunakan metode penelitian hukum normatif yang bersifat preskriptif. Jenis data penelitian berupa data sekunder dengan menggunakan teknik analisis kualitatif. Penelitian ini menghasilkan referensi hukum berupa penelaahan regulasi bagi ojek online di Indonesia dalam perspektif filsafat fenomenologi hukum. Hasil penelitian menunjukkan bahwa Indonesia belum memiliki pengaturan yang secara khusus untuk mengatur payung hukum transportasi ojek online sehingga menimbulkan kekosongan hukum. Dapat disimpulkan bahwa ditinjau dari filsafat fenomenologi, Permenhub Nomor 12 Tahun 2019 tentang Perlindungan Keselamatan Pengguna Sepeda Motor telah mengisi kekosongan hukum yang mengatur tentang ojek online. Namun peraturan tersebut perlu diperbaiki dan disempurnakan agar peraturan yang baru nanti dapat berfungsi sebagai peraturan efektif yang mampu menjawab kebutuhan masyarakat.
\end{abstract}

Kata kunci: regulasi, ojek online, filsafat, fenomenologi, hukum.

\section{Review of Online Ojek Regulation in Indonesia from the Perspective of Phenomenological Philosophy of Law}




\begin{abstract}
Public transportation modes are experiencing technological developments that make it easy for prospective passengers to access, such as from conventional to online transportation. However, the operation of an online transportation service provider company was declared to be running an illegal business because from the start they didn't meet the provisions of article 1 number 21 of Law Number 22 Year 2009 concerning Road Traffic and Transportation (LLAJ Law) and didn't have a business license as a public transportation service provider. Then in 2019 the Minister of Transportation of the Republic of Indonesia issued Ministerial Regulation Number 12 of 2019 concerning Safety Protection of Motorcycle Users Used in Public Interest. This Ministerial Regulation disregards the clutter of other laws and regulations as a new breakthrough which is expected to be a solution to the problem of regulatingmotorcycle taxis online. Based on legal problems related to the regulation ofmotorcycle taxis online, the authors are interested in conducting research on the legal need to regulatemotorcycle taxis online in Indonesia based on the perspective of the philosophy of legal phenomena. This study uses a prescriptive normative legal writing method. This research produces a legal reference in the form of a review of regulations formotorcycle taxis online in Indonesia from the perspective of the philosophy of legal phenomena. The results of the study indicate that Indonesia does not yet have a special arrangement to regulate the legal umbrella for onlinemotorcycle taxi transportation, causing legal problems. It can be said that in terms of phenomenological philosophy, Permenhub Number 12/2019 concerning Protection of Motorcycle User Safety is to fill in the legal column that regulates online motorcycle taxis. However, these regulations need to be improved and refined so that the new regulations can later function as effective regulations and able to answer the needs of the community.
\end{abstract}

Keywords: regulation, ojek online, philosophy, phenomenology, law.

\title{
I. Pendahuluan
}

Amanah konstitusi pada Pasal 33 ayat (4) jelas menyatakan bahwa setiap upaya pembangunan ekonomi wajib dilaksanakan dengan melibatkan kontribusi masyarakat. Asas kemanfaatan sejauh ini menjadi acuan konsep pembangunan ekonomi di tanah air. Artinya, setiap upaya pembangunan ekonomi yang dijalankan pemerintah sudah semestinya akan menghasilkan manfaat bagi kesejahteraan rakyat, serta tak luput harus mampu mengakomodir tiap-tiap kebutuhan rakyat. Pelaksanaan upaya pembangunan ekonomi salah satunya adalah dengan meningkatkan kemudahan akses transportasi di tengah-tengah masyarakat. Transportasi tentu menjadi hal yang signifikan terkait dengan 
kebutuhan masyarakat untuk melaksanakan aktifitas ekonomi sehari-harinya. Sehingga upaya pemerintah untuk meningkatkan kemudahan akses transportasi dapat dinilai sebagai upaya untuk meningkatkan laju perekonomian dan kesejahteraan di tengah masyarakat. (Salim, 2008:10)

Transportasi umum atau angkutan umum merupakan bintang utama yang menjadi fokus pemerintah untuk dimaksimalkan penggunaannya agar mampu mengurai lalu lintas yang dipenuhi kendaraan bermotor khususnya di kota-kota besar. Belakangan ini moda transportasi umum mengalami perkembangan teknologi yang mampu memudahkan akses bagi para calon penumpangnya. Calon penumpang hanya perlu memesan transportasi umum melalui aplikasi di ponsel pintar (smartphone) nya masing-masing. Kemunculan moda transportasi online sejak kurang lebih tujuh tahun terakhir, merupakan layanan yang dimunculkan oleh perusahaan-perusahaan di bidang bisnis pengangkutan berbasis online. Sebutlah Grab, Go-Jek, Uber, sebagai perusahaan besar penyedia jasa transportasi online skala nasional.

Bulan Juli 2019 Komunitas Konsumen Indonesia (KKI) telah melakukan survei kepada para pengguna angkutan umum berbasis online. Hasil Survei mengungkapkan bahwa masyarakat jauh lebih memilih moda transportasi online daripada transportasi umum lainnya. Sebagai gambaran konkret, 625 orang yang dijadikan responden dalam penelitian memberikan pengakuan bahwa 91,7 persen dari mereka adalah pengguna ojek online, 40 persen dari mereka pengguna taksi online, 33.4 persen adalah pengguna KRL, dan 25,1 persen adalah pengguna bus rapid transit (BRT). (Azka, 2019:1) Dari hasil survei tersebut ojek online yang merupakan moda transportasi online berbasis sepeda motor menjadi primadona di kalangan masyarakat. Dewanto dalam hasil penelitiannya di Jakarta pada Tahun 2016 mengungkapkan bahwa ojek online sudah bagaikan 'Pahlawan' penyelamat dari kemacetan dan pengangguran oleh sebagian besar masyarakat ibukota, karena selain kepraktisan dan efisiensi pelayanannya bagi para penumpang, bagi para pengemudi atau driver nya moda transportasi ini mampu membuka peluang pekerjaan baru. (Dewanto, 2016:2) Selain mampu menyediakan lapangan pekerjaan baru, banyak juga masyarakat 
dengan kesibukan seperti mahasiswa dan ibu rumah tangga yang memperoleh tambahan penghasilan dengan menjadi freelance driver sebagai pekerjaan sampingan karena pekerjaan ini fleksibel dan mudah.

Ojek online dan moda transportasi online lainnya disamping menghadirkan berbagai kemudahan yang disambut dengan penuh suka cita oleh masyarakat baik sebagai customer ataupun driver yang sama-sama memperoleh keuntungan berkat kehadiran perusahaan transportasi online, ternyata masih lekat dengan pendapat bervariasi. Ada yang pro dan ada yang kontra di tengah-tengah masyarakat. Bukan menjadi hal yang baru bahwa suatu inovasi akan mengundang pro dan kontra, akan tetapi pro dan kontra yang mengikuti dibelakang kemunculan moda transportasi online ini adalah masalah yang cukup serius mengingat Indonesia merupakan Negara Hukum sebagaimana jelas termaktub di dalam konstitusi Pasal 1 ayat (3).

Perusahaan penyedia jasa transportasi online dinyatakan telah menjalankan sistem operasional bisnis yang ilegal. Hal ini dikarenakan mereka sejak awal tidak memenuhi ketentuan umum angka 21 dalam Undang-Undang Nomor 22 Tahun 2009 tentang Lalu Lintas dan Angkutan Jalan yang secara tegas mengatakan bahwa "Perusahaan Angkutan Umum yang diakui oleh negara adalah suatu badan hukum yang menyediakan jasa pengangkutan baik untuk orang maupun barang dengan kendaraan Bermotor Umum." Perusahaanperusahaan penyedia moda transportasi online di Indonesia seperti Gojek misalnya, menyatakan claim dalam artikel Gojek Bukan Perusahaan Transportasi Umum dan pada situs resmi Go-Jek (terms of use pasal 1.5), bahwa perusahaannya merupakan pelaku usaha penghubung dan mereka adalah Perusahaan Teknologi. Sehingga karena hal tersebut lah tidak ada kewajiban untuk mengantongi izin usaha sebagai perusahaan penyedia transportasi umum. (Warsito, 2017:2)

Akibat dianggap ilegal oleh beberapa orang yang kontra atas kehadiran moda transportasi online dari perusahaan-perusahaan yang memang tidak mengantongi izin sebagaimana diuraikan sebelumnya, kemudian ditambah dengan faktor lain dimana kompetitor yakni para penyedia jasa transportasi 
umum konvensional merasa kehadiran transportasi online ini akan menggerus pendapatan mereka, timbul berbagai protes dan demo di tengah masyarakat yang menuntut agar pemerintah bertindak tegas melarang operasional perusahaan penyedia moda transportasi online tersebut. SE Bupati Banyumas Nomor 551.2/2900/2017 dan SE Walikota Cirebon Nomor 551.2/1315/DISHUB tentang Larangan Operasional Ojek Online, pernah diberlakukan oleh pemerintah daerah Kabupaten Banyumas dan Kota Cirebon untuk melarang moda transportasi online beroperasi didaerahnya dengan dasar legalitas izin operasional yang tidak dikantongi perusahaan.

Permasalahan lainnya yang secara khusus melekat pada operasional Ojek online adalah pengaturan mengenai kendaraan apa yang boleh digunakan untuk menyediakan jasa transportasi umum. Ojek adalah kendaraan berbasis sepeda motor yang keberadaan nya sudah ada sejak lama sebelum munculnya moda transportasi online. Akan tetapi Pasal 47 ayat (3) Undang-Undang Nomor 22 Tahun 2009 tentang Lalu Lintas dan Angkutan Jalan tidak memasukkan sepeda motor kedalam ragam kendaraan bermotor umum yang diatur didalamnya. Mengapa kendaraan sepeda motor beroda dua tidak dimasukkan kedalam ragam kendaraan bermotor umum, hal ini dijelaskan oleh Mahkamah Konstitusi melalui putusannya atas uji materiil perkara Nomor 41/PUU-XVI/2018 tentang permohonan pengujian pasal 47 ayat (3) UU LLAJ.

Putusan Mahkamah Konstitusi tersebut dalam pertimbangannya menjelaskan bahwa kendaraan dengan roda dua tidak masuk dalam kategori kendaraan bermotor umum karena pertimbangan faktor keselamatan, keamanan, dan kenyamanan. Pengaturan pada pasal tersebut dimaksudkan agar angkutan jalan aman digunakan, dan mampu membawa pengemudi, penumpang, juga pengguna jalan lainnya selamat sampai tujuan masing-masing. Dengan penjelasan yang lebih sederhana, sepeda motor bukanlah angkutan jalan yang diperuntukkan mengangkut barang dan/atau orang. (Putusan MK Nomor 41/PUU-XVI/2018, 2018:34) Meski demikian masih dalam putusannya, Mahkamah juga menyatakan tidak menutup mata dengan fenomena sosial yang ada di masyarakat terkait dengan keberadaan ojek. Kapasitas mahkamah dalam 
menjelaskan makna pasal yang diujikan tersebut hanya menjelaskan maksud pembuat Undang-Undang. Mengingat Sepeda Motor secara hukum positif di Indonesia saat ini belum masuk ke dalam ragam kendaraan bermotor umum, maka problematika hukum mengenai operasional ojek online sebagai moda transportasi yang legal semakin rumit jika dilihat dari pasal-pasal bermuatan aturan yang diberlakukan saat ini.

Titik terang dari permasalahan subtansi undang-undang terkait dengan operasional ojek online belum juga diketemukan, namun pada Tahun 2019 Menteri Perhubungan Republik Indonesia justru mengeluarkan Permenhub Nomor 12 Tahun 2019 tentang Perlindungan Keselamatan Pengguna Sepeda Motor yang Digunakan untuk Kepentingan Masyarakat. Permenhub ini keluar menghiraukan kesemrawutan peraturan perundang-undangan lainnya sebagai terobosan baru yang diharapkan dapat menjadi solusi atas permasalahan pengaturan ojek online. Apakah peraturan menteri ini sungguh-sungguh dapat mengurai problematika legalitas ojek online di Indonesia, atau justru menambah persoalan peraturan hukum yang ada di Indonesia mengingat terang sekali peraturan menteri ini bertentangan dengan UU LLAJ yang secara hierarki peraturan perundang undangan merupakan peraturan yang lebih tinggi. Meskipun demikian kehadiran Peraturan Menteri ini dapat mengisi kekosongan hukum mengenai regulasi ojek online di Indonesia saat ini.

Peraturan seharusnya memenuhi unsur sosiologis berupa karya cipta masyarakat guna memenuhi banyak aspek kebutuhan yang menyangkut kondisikondisi tertentu mengenai perkembangan masalah dan kebutuhan rakyat. Selama ini ojek online terus beroperasi dan menjadi jawaban atas kebutuhan (nessity) masyarakat yang perlu diakomodir negara. Ketika Ojek online menjadi tranportasi terbesar dan negara enggan mengaturnya maka yang terjadi adalah pengingkaran negara terhadap kepentingan perlindungan masyarakatnya. Justru disini akan muncul celah dimana pihak swasta atau perusahaan dapat membuat ketentuan yang akan diberlakukan sesuai kehendak mereka diluar kontrol negara. Seperti masalah perlindungan kerja yang lemah (Jam kerja driver bisa melebihi $40 \mathrm{jam} /$ pekan), pendapatan yang mereka peroleh tidak mengenal 
standar upah minimum, driver online juga tidak dianggap sebagai karyawan penyedia aplikasi online. Mereka tidak mendapatkan hak-haknya sebagai karyawan. Hubungan mitra ini membebaskan perusahaan dari kewajiban memenuhi hak-hak karyawan (Soekanto, 2009).

Berdasarkan problematika hukum terkait dengan regulasi ojek online sebagaimana telah dijelaskan sebelumnya, penulis tertarik untuk melakukan penelitian mengenai kebutuhan hukum untuk melakukan regulasi terhadap ojek online di Indonesia. Kondisi saat ini menunjukkan bahwa undang-undang pokok yang mestinya mengatur operasional ojek online belum mengakomodir hal tersebut. UU LLAJ yang dibuat pada masa itu sepertinya sudah tidak relevan lagi dengan berbagai perkembangan yang ada. "Het recht hink achter de feiten ann” yang berarti hukum tertulis selalu tertatih-tatih mengejar ketertinggalannya dari peristiwa yang terjadi. Oleh karena itu, suatu peraturan membutuhkan revisi/perbaikan untuk merespon peristiwa-peristiwa konkrit yang menjadi permasalahan dalam lingkup sosial kemasyarakatan.

Adapun metode yang digunakan dalam penelitian ini adalah penelitian hukum normatif yang bersifat preskriptif (Kuswarno, 2009). Penelitian hukum normatif merupakan istilah lain dari penelitian doktrinal, yaitu penelitian yang didasarkan bahan-bahan hukum primer dan sekunder. Bahan hukum selanjutnya akan disusun sistematis, dikaji secara lebih mendalam, diberikan analisis, dan terakhir akan ditarik kesimpulan yang berhubungan dengan masalah utama penelitian. (Marzuki, 2018:57) Jenis data yang digunakan adalah data sekunder dengan menggunakan teknik analisis kualitatif. Penelitian ini menghasilkan referensi hukum berupa telaah filsafat mengenai regulasi bagi ojek online.

\section{Pembahasan}

\section{A. Hukum Positif Mengatur Regulasi Ojek Online}

Ojek online di Indonesia sebagai salah satu model transportasi yang memudahkan dan menguntungkan bagi konsumen serta mitra ojek online, membuat ojek online saat ini mengalami perbincangan yang sangat ramai di berbagai media, maupun dalam dunia bisnis. Namun pada akhirnya ojek online 
berhasil memikat masyarakat baik dari yang akan menikmati jasa ojek online maupun mitra dari ojek online.

Jumlah penduduk yang bekerja naik hampir di semua sektor jika dibandingkan Agustus 2015, kecuali sektor konstruksi. Sektor konstruksi berkurang jumlah tenaga kerjanya sebanyak 230 ribu orang $(2,80$ persen). Adapun peningkatan jumlah tenaga kerja terutama di bidang sektor jasa kemasyarakatan sebanyak 1,52 juta orang $(8,47$ persen). Selanjutnya sektor perdagangan sebanyak 1,01 juta orang (3,93 persen), serta sektor transportasi, pergudangan, dan komunikasi sebanyak 500 ribu orang (9,78 persen). Kehadiran ojek online membuktikan mengurangi jumlah pengangguran yang ada di Indonesia, terutama di wilayah DKI Jakarta (Mawanda \& Muhshi, 2019:39).

Mahkamah Konstitusi di dalam Putusan Nomor 41/PUU.XVI/2018 dalam amarnya menyatakan permohonan pemohon mengenai uji materiil pasal 47 ayat (3) tidak bertentangan dengan konstitusi sekalipun dalam pasal tersebut tidak memasukkan sepeda motor sebagai moda transportasi umum. Meskipun demikian, majelis hakim MK berpandangan bahwa ketentuan Pasal 47 ayat (3) pada faktanya tidak menghalangi pemohon untuk mendapat pekerjaan dan penghidupan yang layak sebagaimana dalil dari pemohon, karena sepeda motor dalam bentuk ojek motor tetap dapat beroperasi sebagai moda transportasi umum sekalipun pasal yang dimohonkan tersebut tidak mengatur mengenai sepeda motor secara langsung. Realitas hukum mengenai pengaturan sepeda motor sebagai moda transportasi umum menjadi semakin tidak jelas. Walaupun tidak secara rigid dinyatakan terlarang oleh hukum, dan hanya secara implisit tidak termasuk ragam jenis moda transportasi umum yang diakui oleh UndangUndang, namun posisi ini membuat penggunaan sepeda motor sebagai transportasi umum menjadi jauh dari kepastian hukum. Terdapat ketetapan primer yaitu berbadan hukum, dalam perusahaan angkutan umum harus menyelenggarakan angkutan orang dan/ atau barang wajib memiliki (Abdillah, 2019:3):

1. Izin untuk melakukan penerapan angkutan pada lintasan

2. Perizinan untuk melakukan penerapan angkutan orang bukan pada lintasan 
3. Perizinan untuk melakukan penerapan angkutan barang tersendiri

Putusan Mahkamah Konstitusi No.41/PUU.-XVI/2018 belum cukup memberikan kepastian hukum bagi para pengemudi dan penumpang ojek online. Jaminan atas perindungan hukum serta hak atas pekerjaan menjadi terancam karena adanya celah kekosongan hukum mengenai posisi sepeda motor sebagai salah satu ragam jenis moda transportasi umum ini. Hal ini terutama paling berdampak terhadap operasional ojek motor online. Perusahaan start up yang mengoperasikan sepeda motor sebagai salah satu layanan utama nya tidak mengantongi izin operasional sebagai perusahaan penyedia jasa angkutan umum, melainkan hanya sebagai perusahaan teknologi. Karena tidak adanya payung hukum khusus yang mewadahi regulasi terhadap penggunaan sepeda motor sebagai kendaraan umum, izin operasional perusahaan ojek online pun tidak mencakup izin sebagai perusahaan penyedia jasa angkutan orang. Fenomena ini membuat beberapa pihak yang tidak menyukai kehadiran inovasi digital dalam sektor angkutan umum, khususnya sepeda motor ini menganggap operasional dari perusahaan ojek online adalah praktek ilegal. Akibatnya, beberapa daerah yang mengalami kondisi penolakan dari pihak masyarakat menuntut pemerintah daerah untuk bertindak. SE Bupati Banyumas Nomor 551.2/2900/2017 dan SE Walikota Cirebon Nomor 551.2/1315/DISHUB tentang Larangan Operasional Ojek Online, pernah diberlakukan oleh pemerintah daerah Kabupaten Banyumas dan Kota Cirebon untuk melarang moda transportasi online beroperasi didaerahnya dengan dasar legalitas izin operasional yang tidak dikantongi perusahaan.

Adapun kewajiban yang kemudian harus dipenuhi perusahaan angkutan umum ataupun penyedia jasanya (Abdillah, 2019:2):

1. Kewajiaban kepada penyedia jasanya harus sesuai tolak ukur dari layanan yang semestinya yaitu usaha milik daerah serta memiliki badan hukum yang sesuai ketetapan peraturan yang tertulis.

2. Tanda nomor dari kendraan bermotor umum dasar kuning dan tulisan hitam.

3. Kewajiban terhadap keselamatan, rasa aman, nyaman, kesetaraan, terjangkau dan teratur itu harus dipenuhi oleh perusahaan. 
4. Pada kendaraan layanan angkutan orang dalam lintasan serta bukan dalam lintasanpun dengan mobil bus yang umum dan mobil penumpang umum.

Menteri perhubungan melemparkan pengaturan tentang soal ojek online kepada pemerintah daerah sedangkan tidak ada payung hukum di atas Perda tersebut yang kemudian hal ini jelas memperbesar potensi kacaunya peraturan yang dikeluarkan Pemda karena akibat dari ketidakadaan prinsip utama yang bisa dijadikan acuan. Diperkirakan terdapat tiga maalah yang akan muncul jika ojek online tidak memiliki payung hukum di atas Peraturan Daerah (Putri \& Diamantina, 2019:340).

Pertama, pengaturan yang berada dibawah akan cenderung tumpang tindih UU atau ketetapan yang sudah ada diatasnya. Kedua, jika peraturan hanya diatur lewat Permen, maka yang terbenahi hanya persoalan seputar urusan yang dinaungi oleh masing-masing kementerian yang mengatur karena persoalan tentang ojek online sering menyangkut tentang urusan lintas kementerian. Ketiga, seandainya pengaturan diserahkan melalui Perda maka peraturan antar daerah akan berbeda-beda. Pada akhirnya kementerian Perhubungan (Kemenhub) memastikan peraturan ojek online No.12 Tahun 2019 terkait keselamatan terhadap pengguna sepeda motor tersebut yang harus diberikan perlindungan serta dengan tujuan agar mengutamakan kepentingan masyarakat itu sudah ditandatangani tanggal sebelas Maret Tahun 2019. Terdapat empat hal yang diatur dalam Permenhub No.12/2019 yaitu aturan, kemitraan, keselamatan, dan suspensi mitra driver ojek online (Putri \& Diamantina, 2019:340).

Praturan ini mengatur terkait dengan syarat keselamatan serta keamanan para pihak baik mitra dari pengemudi dan pihak perusahaan dari aplikasi tersebut yang mewadahi. Dalam jangkauan pengaturan antara lain wajibnya pihak mitra pengemudi agar mempunyai Surat Izin untuk Mengemudi (SIM), Surat Tanda untuk Kendaraan Bermotor (STNK) yang berlaku saat berkendara serta tidak boleh berpenumpang melebihi dua orang yaitu hanya pengemudi dan penumpangnya. Sedangkan dengan pihak perusahaan aplikasi yang mewadahi para mitra pengemudi juga terdapat kewajiban dalam kelengkapan perangkat lunak tersebut dengan sebutan Panic Button. Sedangkan terdapat Kepmenhub 
No. KP.348/2019 yang kemudian penerbitan ini merancang terkait acuan prinsip pada neraca estimasi harga dari jasa penggunaan sepeda motor yang dilakukan melalui perangkat lunak sehingga aturan ini merupakan formula dari estimasi tarif jasa tersebut. Keputusan Menteri Perhubungan No.348 Tahun 2019 memberikan rincian dari tarif jasa minimal, jasa batas bawah, dan jasa batas atas dengan menerapkan sistem zonasi. Misalnya, Tangerang, Bogor, Jakarta, dan Bekasi berada dizona (2) yang mana tarif zona (2) dengan tarif jasa batas bawah diberlakukan penetapan senilai Rp. 2.000 per kilometer dan untuk tarif jasa atas senilai Rp. 2.500 per kilometer serta tarif jasa minimal dalam rentang senilai Rp.8.000 per kilometer sampai dengan Rp. 10.000 per kilometer.

Pengangkutan menurut hukum pengangkutan yang ada di Indonesia dibagi menjadi dua bagian; pertama, yaitu orang dan yang kedua adalah barang yang diatur pada Pasal 1 angka 3 (UU LLAJ). Adapun jenis kendaraan yang digunakan untuk pengangkutan terbagi dua yang disebut kendaraan bermotor dan kendaran yang bukan bermotor (Astuti, 2019:144-145).

Masyarakat menilai ojek memberikan manfaat yang membantu terhadap kebutuhan transformasi angkutan masal karena efisiensinya serta kecepatannya. Akan tetapi hal tersebut belum sesuai pada regulasi yang ada di Negara Indonesia. Kemudian ojek dengan sepeda motor bermasalah pada legalitasnya serta UU LLAJ sendiri belum ada pasal yang secara pasti tidak memperbolehkan beroperasinya suatu ojek sepeda motor kedalam angkutan publik atau masal (Mawanda \& Muhshi, 2019:39).

\section{Pengaturan Transportasi Angkutan Umum}

Pengangkutan darat diatur dalam UU LLAJ terkait Lalu Lintas serta Angkutan Jalan. Pandangan terhadap Pasal 1 angka 3 bahwa angkutan adalah seseorang serta barang yang berpindah dari tempat semula ke tempat yang lain dengan kendaraan yang penggunaannya di lalu lintas jalan.

Pengangkutan menurut hukum terbagi menjadi dua jenis yaitu orang dan barang tertera pada pasal 1 angka 3 (UU LLAJ) sehingga jika melihat jenisnya: 
1. Angkutan orang maupun barang dilakukan dengan kendaraan yang dilengkapi motor penggerak maupun kendaraan tanpa dilengkapi motor penggerak.

2. Kendaraan yang dilengkapi motor penggerak yang artikan pada ayat (1) huruf a dengan meliputi pengelompokan yaitu kendaraan beroda dua yang sering disebut dengan sepeda motor, kendaraan dilengkapi tempat duduk lebih dari delapan orang bukan termasuk tempat pengemudi (mobil bus), dan mobil barang, serta kendaraan dilengkapi tempat duduk sebanyakbanyaknya delapan orang bukan termasuk tempat pengemudinya (mobil penumpang),

3. Kendaraan tanpa dilengkapi motor penggerak yang diartikan dalam ayat (1) huruf $\mathrm{b}$ terkait mekanisme penggerak dari kendaraan tersebut menggunakan tenaga dari orang maupun dengan tenaga hewan.

Hukum pengangkutan di Indonesia ketika pemerintah melaksanaan pembinaan terhadap kewajiban suatu negara dalam tanggung jawabnya kepada lalu lintas serta angkutan jalan sesuai dengan penjelasan dari pasal 5 ayat (1). Dengan demikian juga oleh pembinaan lalu lintas serta angkutan jalan djalankan instasi Pembina sesuai tugas dan fungsinya (Purwosutjipto, 1987).

Pasal 14 ayat (1) PP No.74 Tahun 2014 menyatakan bahwa angkutan masal diterapkan agar mencukupi kebutuhan dari angkutan jenis orang maupun barang tersebut dengan kenyamanan, keamanan, keselamatan serta tercapai. Tanggung jawab dalam penyelenggaraan tersebut di atur pada pasal 14 ayat (2). Sedangkan tanggung jawab Pemerintahan Pusat, Provinsi, Kabupaten berdasarkan dari tanggung jawabnya ditentukan oleh PP no.74 /2014 yaitu sebagaimana pada pasal 15 ayat (1) pemerintah sendiri wajib atas jaminannya untuk ketersediaan angkutan masal bagi jasa angkutan antarkota maupun wilayah serta rute batas negara.

Ketika dilihat dari segi pengaturan hukum yang terdapat di Indonesia bahwa perusahaan pengangkutan umum terkait ojek online belum diatur ke dalam UU LLAJ serta pada PP No.74/2014. Namun, jika dilihat pada penafsiran terhadap pengangkutan umum itu sendri merupakan kendaraan yang digunakan untuk 
pengangkutan umum yaitu kendaraan dengan motor penggerak masal dengan artian setiap kendaraan yang dilengkapi motor penggerak kemudian penggunaanya dibuat pada angkutan orang maupun barang beserta adanya biaya yang diambil. Oleh karena itu, pihak perusahaan transportasi ojek online dengan contoh seperti Go-Jek, Maxim Transportation, Ojek Kampus, GrabBike, Uber dan lain-lain yang mempersiapkan jasa pengangkutan orang dan barang melalui aplikasi dari ponsel dengan adanya pembayaran yang diterapkan kepada penumpang atau pengirim barang tersebut masuk dalam pengertian pengangkutan umum.

Pihak perusahaan angkutan publik yang sinkron terhadap peraturan tertulis yang berlaku kemudian wajib berbentuk badan hukum seperti diatur pada ketentuan Pasal 79 PP No. 74 Tahun 2014 yaitu :

1. Perusahaan angkutan publik yang diartikan pada Pasal 78 ayat (1) harus berupa badan hukum yang sinkron terhadap ketetapan peraturan tertulis yang berlaku di Indonesia.

2. Badan hukum tersebut diartikan yang terdapat dalam ayat (1) berupa: BUMN, BUMD, PT, KSP.

Pihak perusahaan transportasi ojek online tersebut misalnya Go-Jek dengan badan hukum Perseroan Terbatas yaitu Go-Jek Indonesia, Grab dengan badan hukum yaitu Koperasi Jasa Usaha Bersama.

\section{B. Regulasi Ojek Online dalam Prespektif Filsafat Fenomenologi Hukum}

Analisis terhadap peraturan ojek online yang terdapat dalam UndangUndang Nomor 22 Tahun 2009 tentang Lalu Lintas dan Angkutan Jalan (UU LLAJ) dan Permenhub Nomor 12 tahun 2019 tentang Keselamatan Pengguna Sepeda Motor dilihat dari prespektif kajian filsafat fenomenologi oleh Edmud Gustav Albercht Husserl dan kemudian mengenai eksistensinya dapat dikaji melalui perkembangan sejarah dengan mengaitkannya pada mahzhab/aliran hukum sejarah oleh Frederic Carl Von Savigny yang dapat diuraikan dalam sub pembahasan ini sebagai berikut.

Saat ini, fenomenologi telah menjadi mazhab filosofi, dan merupakan cara berpikir yang mempelajari fenomena manusia tanpa meragukan penyebab 
fenomena ini serta realitas dan penampakan obyektifnya. Istilah fenomenologi diambil dari bahasa Yunani, dan asal-usulnya adalah "fenomena' dan "logos". Fenomena mengacu pada muncul dalam kesadaran manusia. Logos berarti pengetahuan. Fenomenologi mengacu pada studi tentang fenomena atau penampilan mereka sendiri (Diyarkara, 1978:122). Obyek fenomenologi adalah fakta atau gejala, atau kondisi, peristiwa atau obyek, atau realitas sedang mengalami suatu fenomena.

Prespektif peraturan yang terdapat di dalam UU LLAJ dan Permenhub Nomor 12 Tahun 2019 tentang Keselamatan Pengguna Sepeda Motor, dalam hal ini dilihat dari filsafat fenomenologi tidak hanya sekededar melindungi dan sebagai dasar hukum para pengguna sepeda motor atau ojek online, akan tetapi harus melihat fakta kenyataan yang ada di lapangan, artinya peraturan tersebut tidak hanya sekedar dapat melindungi para pelaku ojek online akan tetapi peraturan tersebut juga harus memperhatikan dampak terhadap sesama ojek lain bahkan kepada masyarakat pengguna ojek online tersebut.

Fenomonelogi menurut Edmud Husserl tidak hanya sekedar melindungi sebagai pelaku ojek online tetapi dalam kajian filsafat mestinya tidak hanya melindungi ojek online saja, seharusnya juga dapat melindungi ojek yang lain dan masyarakat. Dalam filsafat ini bukan hanya sekedar perlindungan hukum dari peraturan tersebut namun harus mampu memberikan ketenangan, ketenteraman, dan kesejahteraan terhadap masyarakat apakah itu masyarakat pengguna maupun sesama pelaku ojek lain.

Hakikat dari filsafat fenomenologi adalah kemampuan seseorang berfikir dengan akalnya terhadap fenomena, gejala atau kejadian yang timbul dalam masyarakat. Misalnya munculnya ojek online disamping biaya murah, dapat memberikan kemudahan dan kecepatan bagi para pengguna ojek online. Hal itu menurut filsafat fenemologi, UU LLAJ dan Permenhub Nomor 12 Tahun 2019 tentang Perlindungan Pengguna Sepeda Motor, harus juga dapat memberikan perlindungan hukum dan kenyamanan bagi pelaku penjual jasa transportasi yang lain misalnya taxi, becak tradisional, maupun penjual transportasi lainya. 
Fakta fenomelogi setelah munculnya ojek online dalam masyarakat yang dilindungi oleh undang- undang tersebut kenyataanya di protes oleh masyarakat yang sama-sama sebagai pelaku penjual jasa trasnportasi misalnya taxi, becak tradisional, maupun penjual transportasi lainya oleh masyarakat. Hal tersebut merupakan fakta fenomelogi obyektif yang terjadi/muncul di dalam masyarakat.

Fakta sangat fenomenal yang muncul dalam masyarakat yaitu lahirnya atau munculnya Surat Edaran Bupati Banyumas dan Walikota Cirebon yang mana mengeluarkan Surat Edaran Nomor 551.2/2900/2017 dan Surat Nomor 551.2/1315/DISHUB tentang Larangan Operasional Ojek Online. Tujuan dari Surat Edaran tersebut memang baik dikarenakan melindungi warganya yang juga sebagai penjual jasa transportasi lain agar tidak kalah saing dengan transportasi ojek online, namun Surat Edaran Bupati tersebut sebenarnya isinya tidak sejalan atau bertentangan dengan Peraturan Menteri Perhubungan Nomor 12 Tahun 2019 tentang Keselamatan Pengguna Sepeda Motor, karena menurut hirarki Peraturan Perundang- Undangan, peraturan yang ada di bawah tidak boleh bertentangan dengan peraturan diatasnya.

Menurut utilitarianisme dan filsafat ilmu tentang axiology bahwa, filsafat ini mengedepankan sebuah kemanfaatan cara perpikir seseorang sehingga hasil dari buah pemikiran tersebut dapat diperggunakan untuk kebaikan masyarakat bersama. Seharusnya dengan adanya dalam Undang Undang Nomor 22 Tahun 2009 tentang Lalu Lintas dan Angkutan Jalan dan Peraturan Menteri Perhubungan Nomor 12 tahun 2019 tentang Keselamatan Pengguna Sepeda Motor menurut kajian utilitarianisme dan filsafat ilmu axiology peraturan tersebut tidak hanya bermanfaat terhadap ojek online akan tetapi juga harus bermanfaat terhadap jasa transportasi yang ada dalam masyarakat selain ojek online, misalnya taxi, becak tradisional, dan jasa transportasi lainya oleh masyarakat. Oleh karena itu, Peraturan Menteri Perhubungan Nomor 12 Tahun 2019 tentang Keselamatan Pengguna Sepeda Motor sebaiknya perlu dikaji ulang dan disempurnakan agar menjadi sebuah peraturan baru yang melindungi semua pelaku jasa transportasi yang ada dalam masyarakat baik ojek online maupun jasa transportasi lainnya. 
Selain itu, keberadaan kreativitas dalam rekayasa alat ojek online dapat dipelajari dengan menggunakan teori hukum sejarah (muncul dari tahun 1770 hingga 1861). Frederic Carl Von Savigny mengibaratkan kemunculan hukum dengan bahasa suatu negara dengan segala ciri dan karakteristiknya. Karena hukum merupakan salah satu faktor dalam kehidupan bersama suatu negara, seperti bahasa, adat istiadat, kesusilaan, dan ketatanegaraan. Oleh karena itu hukum adalah hal super personal, fenomena sosial. Menurutnya, terciptanya hukum bukan karena tatanan atau kebiasaan penguasa, melainkan karena rasa keadilan yang ada pada jiwa bangsa. Jiwa negara adalah sumber hukum. Hukum tidak dirumuskan, tetapi dikembangkan bersama masyarakat. (Nasution, 2016:101)

Dalam aliran sejarah menurut Savigny, hukum dihasilkan bukan karena dirumuskan secara lengkap oleh penguasa, tetapi karena erat kaitanya dengan sosial budaya. Dilihat dari prespektif sejarah, hukum lahir karena aktivitas kehidupan masyarakat yang muncul dan terjadi dalam masyarakat, dimana dalam aktivitas tersebut benar-benar merupakan hasil budidaya dan pikiran manusia untuk menjawab dan mengatasi tantangan kehidupan baik secara ekonomi, sosial, dan budaya yang kemudian berkembang dan berlaku dalam kehidupan masyarakat.

Perlakuan yang muncul dari dalam masyarakat tersebut agar terjadi kehidupan yang tertib, teratur dan saling menghargai hak dan kewajibannya, maka akan melahirkan keinginan bersama membuat suatu peraturan yang disepakati dan dijalankan bersama agar aktivitas kehidupan tersebut menjadi tertata dengan baik secara guyub, rukun, dan manunggal. Dari keinginan yang dikehendaki masyarakat untuk membuat kesepakatan bersama itulah melahirkan peraturan-peraturan yang diciptakan oleh masyarakat dan ditaati secara bersama.

Dalam prespektif sejarah dinyatakan bahwa lahirnya sebuah Peraturan Perundang-Undangan bukan merupakan kehendak negara akan tetapi kehendak masyarakat bersama yang kemudian negara ikut campur kemudian merespon membuatkan sebuah Peraturan Perundang-Undangan yang isinya mengatur perilaku kehidupan masyarakat tersebut. 
Misalnya dalam kenyataan sejarah baru memperlihatkan pada kita bahwa aktivitas kegiatan masyarakat dalam mempertahankan kehidupanya dari segi ekonomi maka lahirlah sejarah baru alat jasa transportasi modern yang disebut dengan jasa ojek online. Dari jasa transportasi modern ojek online yang muncul dan berkembang dalam masyarakat maka direspon oleh penguasa negara yang berwenang membuatkan sebuah peraturan yang mengatur tata aktivitas kehidupan tersebut, misalnya muncul lah dengan Permenhub Nomor 12 Tahun 2019 tentang Keselamatan Pengguna Sepeda Motor.

Ternyata didalam sejarah baru kehidupan ojek online yang melahirkan sebuah peraturan menteri dengan Permenhub Nomor 12 Tahun 2019 tentang Keselamatan Pengguna Sepeda Motor, dalam perkembangannya terjadi pro dan kontra maka munculah protes didalam masyarakat yang nampaknya peraturan yang dibuat oleh mentri perhubungan tersebut kurang mengakomodir seluruh jasa transportasi baik ojek online maupun offline.

Ada kemungkinan dari perkembangan yang berlaku dalam kehidupan masyarakat terhadap Peraturan Mentri Perhubungan tersebut nampaknya akan mencatat sejarah kehidupan baru didunia hukum yaitu pemerintah sebaiknya merespon fakta kenyataan dalam masyarakat dan harus memperbaiki dan menyempurnakan perturan tersebut yang mampu mengakomodir semua jasa transportasi baik ojek online maupun offline.

\section{Penutup}

\section{A. Kesimpulan}

Payung hukum bagi ojek online di Indonesia saat ini adalah Permenhub 12/2019 dengan dicantumkannya UU LLAJ para pembaca memaknai sepeda motor dalam pengesahaannya sebagai jenis kendaraan umum yang baru. Namun, pemaknaan tersebut ternyata bukan sebenarnya yang dimaksudkan oleh pemerintah ketika dilihat lebih mendalam karena perumusan tersebut menghindari istilah dari kendaraan bermotor umum, angkutan umum atau angkutan orang. Kemudian, Permenhub 12/2019 memberikan sifat-sifat kendaraan umum untuk kendaraan bermotor yang digunakan perseorangan 
dengan pada akhirnya tidak memberikan kejelasan status hukum ojek online. Pada Permenhub 12/2019 dan Kepmenhub 384/2019 belum memberikan ruang operasional ojek online untuk diatur oleh Pemerintah Daerah karena dalam pasal Permenhub 12/2019 menyebutkan bahwa Pemerintah Daerah hanya memberlakukan suatu pengawasan penggunaan sepeda motor untuk kepentingan masyarakat dengan begitu tidak jelas Pemerintah Daerah diperbolehkan atau tidak dalam menentukan regulasi ojek online tersebut.

Angkutan umum di Indonesia juga di atur dalam UU LLAJ maupun PP No. 74 Tahun 2014 mengenai Angkutan Jalan juga belum memiliki pengaturan yang secara khusus untuk mengatur payung hukum transportasi ojek online tersebut sehingga menimbulkan kekosongan hukum yang diakibatkan oleh semakin banyaknya ojek online. Selain itu mengenai adanya Permenhub Nomor 12 Tahun 2019 tentang Perlindungan Keselamatan Pengguna Sepeda Motor, ditinjau dari filsafat fenomenologi penulis setuju dengan adanya peraturan tersebut yang mengisi kekosongan hukum yang mengatur tentang ojek online. Namun selain menyatakan persetujuan karena peraturan tersebut dianggap perlu, penulis juga menyatakan bahwa Permenhub Nomor 12 Tahun 2019 tentang Perlindungan Keselamatan Pengguna Sepeda Motor itu perlu diperbaiki dan disempurnakan agar peraturan yang baru nanti benar-benar dapat berfungsi sebagai peraturan efektif yang mampu menjawab kebutuhan masyarakat.

\section{B. Saran}

Sebagai negara hukum Indonesia seharusnya memberikan payung hukum yang tepat bagi keberadaan ojek online. Kurang jelasnya dalam regulasi menimbulkan pemaknaan yang berbeda-beda dimata masyarakat sehingga membuat kegaduhan. Pemerintah perlu melakukan kajian komparasi terhadap negara lain yang sudah mengatur tegas mengenai regulasi ojek online seperti Thailand, Amerika Serikat, dan Singapore. sehingga hukum tidak akan tertinggal oleh fenomena baru dilingkungan masyarakat. Regulasi ojek online di Indonesia perlu diperbaiki. Pemerintah sebaiknya segera melakukan revisi terhada Undang-Undang Nomor 22 Tahun 2009 Tentang Lalu Lintas dan Angkutan Jalan dengan mempertegas posisi sepeda motor sebagai moda 
transportasi umum sebelum kemudian mengatur secara lebih lanjut mengenai teknis perlindungan hukum bagi penggunanya melalui peraturan dibawahnya, baik melalui Peraturan Pemerintah ataupun Peraturan Daerah. Permenhub Nomor 12 Tahun 2019 dapat dijadikan sebagai solusi sementara untuk mengisi kekosongan hukum mengenai regulasi ojek online, namun sudah semestinya peraturan paten yang utama segera disempurnakan.

\section{Daftar Pustaka}

Abdillah, A. (2019). Regulasi Pemberian Izin Usaha Ojek Online. Jurnal Universitas Sriwijaya, 1(3).

Astuti, N. K. (2019). Perlindungan Hukum Terhadap Pelaku Usaha Dan Pengguna Jasa Transportasi Ojek Online Dalam Perkembangan Dinamika Hukum Dan Masyarakat. Jurnal Hukum, 5(3). https://doi.org/10.33541/JtVol5Iss2pp102

Azka, R. M. (2019). Hasil Survei: Masyarakat Pilih Ojol dan Taksol Ketimbang Transportasi Umum. Diambil 10 November 2020, dari Ekonomi Bisnis website: https://ekonomi.bisnis.com/read/20190730/98/1130523/hasilsurvei-masyarakat-pilih-ojol-dan-taksol-ketim bang-transportasi-umum

Dewanto, A. F. (2016). Pengaruh Ojek Online Terhadap Transportasi Masyarakat DKI. Diambil 10 November 2020, dari Adityafajard Blogspot website: http://adityafajard.blogspot.co.id/2016/04/penelitian-ilmiahpenga ruhojek-online.html

Diyarkara, N. (1978). Percikan Filsafat. Jakarta: PT Pembangunan.

Kuswarno, E. (2009). Metodologi Penelitian Komunikasi, Fenomenologi: Konsepsi, Pedoman dan Contoh Penelitiannya. Bandung: Widya Padjadjaran.

Marzuki, P. M. (2018). Penelitian Hukum. Jakarta: Kencana Prenadamedia.

Mawanda, M. K., \& Muhshi, A. (2019). Perlindungan Hukum Mitra Ojek Daring di Indonesia. Lentera Hukum, 6(1). https://doi.org/10.19184/ejlh.v6i1.9203 
Nasution, M. S. A. (2016). Hukum Dalam Pendekatan Filsafat. Jakarta: PT Kharisma Putra Utama.

Purwosutjipto, H. M. . (1987). Pengertian Pokok Hukum Dagang Indonesia: Hukum Pengangkutan. Jakarta: Djambatan.

Putri, H. S., \& Diamantina, A. (2019). Perlindungan Hukum Terhadap Keselamatan Dan Keamanan Pengemudi Ojek Online Untuk Kepentingan Masyarakat. Jurnal Pembangunan Hukum Indonesia, 1(3). https://doi.org/10.14710/jphi.v1i3.392-403

Republik Indonesia. Peraturan Pemerintah Nomor 74 Tahun 2014 Tentang Angkutan Jalan.

Republik Indonesia. Putusan Mahkamah Konstitusi Nomor 41/PUU-XVI/2018 perihal pengujian Undang-Undang Republik Indonesia Nomor 22 Tahun 2009 tentang Lalu Lintas dan Angkutan Jalan terhadap Undang-Undang Dasar Negara Republik Indonesia Tahun 1945.

Republik Indonesia. Undang-Undang Dasar Negara Republik Indonesia 1945.

Republik Indonesia. Undang-Undang Nomor 22 Tahun 2009 Tentang Lalu Lintas dan Angkutan Jalan.

Salim, A. (2008). Manajemen Transportasi. Jakarta: PT Raja Grafindo Persada.

Soekanto, S. (2009). Peranan Sosiologi Suatu Pengantar. Jakarta: Rajawali Press.

Warsito. (2017). Legalitas Moda Transportasi Berbasis Online Dampaknya bagi Pemerintahan Joko Widodo. Prosiding Seminar Nasional Multi Disiplin Ilmu \& Call for papers UNISBANK Ke-3 (SENDI_U 3) 2017. 